\title{
Novel Neodymium(III) Membrane Sensor based on $N$-(2-Furylmethylene)pyridine-2,6-diamine
}

\author{
Parviz Norouzi, ${ }^{*, a}$ Mohammad Reza Ganjali, ${ }^{a}$ Asieh Ahmadalinezhad ${ }^{b}$ and Mehdi Adib $^{a}$ \\ ${ }^{a}$ Department of Chemistry, University of Tehran, Tehran, Iran \\ ${ }^{b}$ Faculty of Chemistry, Tarbiat Moallem University, Tehran, Iran
}

\begin{abstract}
Através de nossos estudos, encontramos que $N$-(2-furilmetileno) piridina-2,6-diamina (FPD) pode ser usado como um excelente ionóforo na construção de um novo sensor baseado em membrana de poli(vinil cloreto) (PVC). Uma composição para a membrana, de $33 \%$ de PVC, $59 \%$ de nitrobenzeno (NB), $6 \%$ de FPD e $2 \%$ de borato de potássio tetrakis ( $p$-clorofenil) (KTpCIPB), levou a ótimos resultados. A seletividade do sensor frente a $\mathrm{Nd}(\mathrm{III})$, é relativamente boa em comparação com um grande número de íons de lantanídeos, tais como lantânio, cério, gadolínio, samário, térbio, európio, disprósio, e itérbio. A resposta do sensor é Nernstiniana (com inclinação de 19,6 \pm 0,3 mV per década para íon carregado triplamente) em um largo intervalo de concentração $\left(1,0 \times 10^{-5}\right.$ a $\left.1,0 \times 10^{-2} \mathrm{~mol} \mathrm{~L}^{-1}\right)$ com limite de detecção de $7,0 \times 10^{-6}$ mol L ${ }^{-1}$, tempo de resposta relativamente rápido em todo intervalo de concentração $(<15 \mathrm{~s})$, e um tempo de vida considerável, de no mínimo seis semanas no intervalo de $\mathrm{pH}$ de 4,0 a 8,0.
\end{abstract}

We found that $N$-(2-furylmethylene) pyridine-2,6-diamine (FPD) can be used as an excellent ionophore in the construction of a novel neodymium(III) poly(vinyl chloride) (PVC)-based membrane sensor. A membrane composition of 33\% poly (vinyl chloride), 59\% nitrobenzene (NB), $6 \% \mathrm{FPD}$, and $2 \%$ potassium tetrakis ( $p$-chlorophenyl) borate (KTpClPB), led to the optimum results. The $\mathrm{Nd}(\mathrm{III})$-selectivity of the sensor, is relatively good in comparison to a large number of lanthanide metal ions, such as lanthanum, cerium, gadolinium, samarium, terbium, europium, dysprosium, and ytterbium ions. The sensor response is Nernstian (with slope of $19.6 \pm 0.3 \mathrm{mV}$ per decade for the triply charged ion) over a wide concentration range $\left(1.0 \times 10^{-5}\right.$ to $\left.1.0 \times 10^{-2} \mathrm{~mol} \mathrm{~L}^{-1}\right)$ with a detection limit of $7.0 \times 10^{-6} \mathrm{~mol} \mathrm{~L}^{-1}$, a relatively fast response time, in the whole concentration range $(<15 \mathrm{~s})$, and a considerable life time of at least six weeks in the $\mathrm{pH}$ range of $4.0-8.0$.

Keywords: neodymium(III), sensor, potentiometry, PVC, $\mathrm{N}$-(2-furylmethylene) pyridine2,6-diamine

\section{Introduction}

Neodymium is the most abundant of the rare earths, after cerium and lanthanum. It shows similar characteristics to the other trivalent lanthanides. Primary applications include lasers, glass coloring and tinting, dielectrics, and most importantly, as the fundamental basis for neodymiumiron-boron $\left(\mathrm{Nd}_{2} \mathrm{Fe}_{14} \mathrm{~B}\right)$ permanent magnets. Neodymium has a strong absorption band centered at $580 \mathrm{~nm}$, which is very close to the human eyes maximum level of sensitivity making it useful in protective lenses for welding goggles. Neodymium salts are used as catalysts in polymerization of 1,3-butadiene and isoprene. ${ }^{1,2}$

*e-mail: norouzi@khayam.ut.ac.ir
The common methods for determination of $\mathrm{Nd}^{3+}$ ion are spectrophotometry, atomic absorption spectroscopy (AAS), and inductively coupled plasma atomic emission spectroscopy (ICP AES). ${ }^{3}$ The spectrometry method suffer from the lack of selectivity and the AAS and ICP AES have higher amounts of detection limit for lanthanide ions (in the case of $\mathrm{Nd}^{3+}$ ion, $60 \mathrm{ppm}$ and $20 \mathrm{ppb}$ for AAS and ICP AES respectively).

Solvent polymeric membrane based ion-selective electrodes (ISEs), prepared by the incorporation of new ionophores, have shown to be very useful tools for clinical, environmental and chemical analysis as well as for process monitoring. A great emphasis, in this field, has been focused on the development of new and highly selective ion-carriers, which can be used in the fabrication of a new ion-specific ISEs with high selectivities and 
sensitivities, wide linear concentration ranges, long lifetime, and good reproducibilities.

There have been many studies on ion-selective electrodes for transition and heavy metal ions. ${ }^{4}$ Among these metal ions, a little attention has been paid to the development of lanthanide electrodes, ${ }^{5-24}$ and especially $\mathrm{Nd}(\mathrm{III}) .^{25}$ Although, this sensor has good sensitivity but in the case of selectivity has serious interferences (especially for $\mathrm{Cu}^{2+}$ and $\mathrm{Yb}^{3+}$ ).

Due to the vital importance of neodymium in industry, and the need for an $\mathrm{Nd}(\mathrm{III})$-selective electrode for the potentiometric monitoring of $\mathrm{Nd}(\mathrm{III})$, we were interested to prepare a novel sensor for the determination of $\mathrm{Nd}(\mathrm{III})$ ions based on $N$-(2-furylmethylene) pyridine-2,6-diamine (FPD) with higher selectivity than previously reported.

\section{Experimental}

\section{Reagents}

Reagent grade dibutyl phthalate (DBP), benzyl acetate (BA), acetophenon (AP), nitrobenzene (NB), potassium tetrakis ( $p$-chlorophenyl) borate $(\mathrm{KTpClPB})$, tetrahydrofuran (THF), and high relative molecular weight PVC were purchased from Merck and used as received. Neodymium chloride and the nitrate salts of neodymium and other cations used (all from Merck, Aldrich and Fluka), were of the highest purity available and used without any further purification except for vacuum drying over $\mathrm{P}_{2} \mathrm{O}_{5}$. 2-furaldehyde, 2,6diaminopyridine, acetic acid, ethanol and methanol (all from Merck), were of the highest purity available. Triply distilled de-ionized water was used throughout.

\section{Synthesis of FPD}

For the preparation of $\mathrm{N}$-(2-furylmethylene)pyridine2,6-diamine, a mixture of 2-furaldehyde $(0.01 \mathrm{~mol}, 0.96$ g), 2,6-diaminopyridine ( $0.01 \mathrm{~mol}, 1.09 \mathrm{~g})$ and catalytic amount of acetic acid, was refluxed for $1 \mathrm{~h}$ in absolute ethanol $(20 \mathrm{~mL})$. Then the mixture was cooled to the room temperature. The resulted pale yellow precipitate was filtered, washed with ethanol, and dried under reduced pressure.

mp $230{ }^{\circ} \mathrm{C}$ (decomp), 1.6 g, yield 89\%; IR (Schimadzu IR-460 Spectrometer, KBr) $v_{\max } / \mathrm{cm}^{-1}: 3342$ and 3196 $\left(\mathrm{NH}_{2}\right), 1589(\mathrm{C}=\mathrm{N}), 1468,1429,1354,1232,1123,997$, 777, 764. MS (FINNIGAN-MATT 8430 at $20 \mathrm{eV}$ ), $\mathrm{m} / \mathrm{z}$ (\%): $187\left(\mathrm{M}^{+}, 100\right), 164$ (24), 88 (17), 28 (15). Anal. Calc. for $\mathrm{C}_{10} \mathrm{H}_{9} \mathrm{~N}_{3} \mathrm{O}$ (187.20): C, 64.16; $\mathrm{H}, 4.85 ; \mathrm{N}, 22.45$. Found: C, 64.3; H, 4.9; N, 22.3\%. ${ }^{1} \mathrm{H}$ NMR (250.1 MHz Bruker, DMSO- $d_{6}$ solution): $\delta 6.28(1 \mathrm{H}, \mathrm{d}, J 6.9 \mathrm{~Hz}, \mathrm{CH}), 6.42$
$(1 \mathrm{H}, \mathrm{dd}, J 3.7 \mathrm{~Hz}$ and $J 1.5 \mathrm{~Hz}, \mathrm{CH}), 6.66(1 \mathrm{H}, \mathrm{dd}, J 3.7$ $\mathrm{Hz}$ and $J 1.0 \mathrm{~Hz}, \mathrm{CH}), 6.84(1 \mathrm{H}, \mathrm{d}, J 7.0 \mathrm{~Hz}, \mathrm{CH}), 6.99(1$ $\mathrm{H}, \mathrm{d}, J 6.8 \mathrm{~Hz}, \mathrm{CH}), 7.36(1 \mathrm{H}$, dd, $J 1.5 \mathrm{~Hz}$ and $J 1.0 \mathrm{~Hz}$, $\mathrm{CH}), 7.95(1 \mathrm{H}, \mathrm{s}, \mathrm{N}=\mathrm{CH}), 8.20\left(2 \mathrm{H}, \mathrm{br}, \mathrm{NH}_{2}\right) ;{ }^{13} \mathrm{C} \mathrm{NMR}$ : $\delta 107.36,108.21,113.52,117.98,131.029$, and 145.54 (6 CH), 157.87, 158.46, and 159.23 (3 C), $160.18(\mathrm{CH})$.

\section{Electrode preparation}

$33 \mathrm{mg}$ of powdered PVC, $59 \mathrm{mg}$ of NB, $6 \mathrm{mg}$ FPD and $2 \mathrm{mg}$ of $\mathrm{KTpClPB}$ were dissolved and mixed in $5 \mathrm{~mL}$ of fresh THF, in order to prepare a membrane of optimum composition and behavior. The resulted mixture was transferred into a glass dish of $2 \mathrm{~cm}$ in diameter, and its solvent was slowly evaporated, until an oily concentrated mixture was obtained.

A final membrane of about $0.3 \mathrm{~mm}$ thickness was formed on the tip of a Pyrex tube (3-5 mm i.d.), by dipping the tube into the mixture for $10 \mathrm{~s}$, pulling it out of the mixture and keeping it at room temperature for $12 \mathrm{~h}$.

The tube, containing the membrane, was filled with internal filling solution $\left(1.0 \times 10^{-3} \mathrm{~mol} \mathrm{~L}^{-1} \mathrm{NdCl}_{3}\right)$ in the next step. The resulting membrane electrode was finally conditioned for $24 \mathrm{~h}$ by soaking in a $1.0 \times 10^{-2} \mathrm{~mol} \mathrm{~L}^{-1}$ solution of neodymium nitrate. For a comparative study, a membrane containing no active component was also prepared. The ratio of different membrane ingredients, concentration of equilibrating solution and the time of contact were optimized to provide membranes, which result in reproducible, noiseless and stable potentials.

\section{Emf measurements}

All emf measurements were carried out with the following assembly:

$\mathrm{Ag}-\mathrm{AgCl}$ internal solution $\left(1.0 \times 10^{-3} \mathrm{~mol} \mathrm{~L}^{-1} \mathrm{NdCl}_{3}\right)$ | PVC membrane| sample solution| $\mathrm{Hg}-\mathrm{Hg}_{2} \mathrm{Cl}_{2}, \mathrm{KCl}$ (satd.)

A Corning ion analyzer $250-\mathrm{pH} / \mathrm{mV}$ meter was used for potential measurements at $25.0{ }^{\circ} \mathrm{C}$.

\section{Results and Discussion}

\section{Potential responses}

Some neutral ion carriers, containing nitrogen and sulfur donor atoms have been reported to use in the construction of the highly selective transition and heavy metal ion membrane sensors, lately. ${ }^{12-19}$

FPD (Figure 1), having one-oxygen and three donating nitrogen atoms in its structure was expected to act as a 
<smiles>Nc1cccc(/N=C/c2ccco2)n1</smiles>

Figure 1. Structure of ionophore FPD.

suitable ion carrier for special transition and heavy metal ions (due to their higher charge density), in the PVC membranes. Thus, at first, FPD was used as a neutral carrier to prepare PVC-based membrane electrodes for a variety of trivalent transition metal ions, including lanthanum, cerium, neodymium, samarium, europium, gadolinium, terbium, dysprosium, and ytterbium ions. The potential responses of the most sensitive ion-selective membrane electrodes based on FPD are shown in Figure 2. It is obvious that, among the nine lanthanide ions tested, $\mathrm{Nd}(\mathrm{III})$, with the most near-to-Nerstian response, can be suitably determined with the PVC membrane sensor based on FPD. This is probably due to both the selective behavior of the ionophore against neodymium (with relatively low charge density and hydration energy), in comparison to other metal ions and the rapid exchange kinetics of the resulting FPD-neodymium complex.

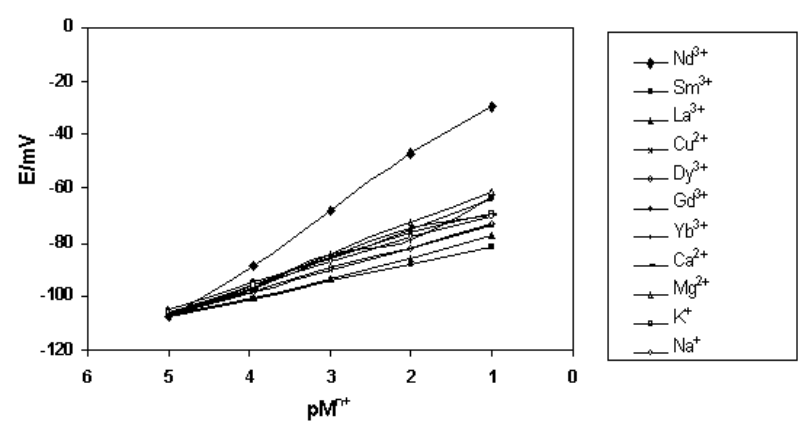

Figure 2. Potential responses of various metal ion-selective electrodes based on FPD (membrane No. 6).

Table 1. Optimization of membrane ingredients

\section{Effect of membrane composition}

It is well known that some important features of the PVC-based membranes, such as the nature and amount of ion-carrier, the properties of the plasticizer, the plasticizer/ PVC ratio and, especially, the nature of additives used, significantly influence the sensitivity and selectivity of the ion-selective electrodes. ${ }^{26,27}$ To study the effects of these parameters, different aspects of preparing a membrane based on FPD, were optimized (Table 1).

The results show that the quantity of FPD affects the sensitivity of the membrane electrode (No. 1-4). The sensitivity of the electrode response increases with increasing ion-carrier content until a value of $6 \%$ is reached.

The solvent mediator/PVC ratio in solvent polymeric membrane ion-selective electrodes is usually found to be about 2 , because polymeric films with such a plasticizer/ PVC ratio will result in optimum physical properties and high enough mobility of their constituents. In this study, the same plasticizer/PVC ratio (about 2) was found to be the most suitable, for the construction of the membrane sensors.

The selectivity and working concentration range of membrane sensors are also affected by the nature and amount of the plasticizers used. This is due to the influence of the plasticizer on the dielectric constant of the membrane phase, the mobility of the ion-carrier molecules, and on the state of complex. The results of Table 1 shows that among the four different plasticizers used, NB (No. 6) having a higher polarity than the other three, namely DBP, AP and BA, is a more effective solvent mediator in preparing the neodymium membrane sensor.

The optimum perm-selectivity of membrane sensors is known to be highly dependent on the incorporation of additional membrane compounds..$^{28}$ It is has been accepted that, the presence of suitable negatively charged lipophilic additives, improves the potentiometric behavior of certain cation-selective electrodes. The data given in Table 1

\begin{tabular}{|c|c|c|c|c|c|}
\hline \multirow[t]{2}{*}{ Membrane No. } & \multicolumn{4}{|c|}{ Composition / (\%) } & \multirow[t]{2}{*}{ Slope / $\left(\mathrm{mV}\right.$ decade $\left.{ }^{-1}\right)$} \\
\hline & PVC & Plasticizer & Additive & Ionophore & \\
\hline 1 & 33 & $\mathrm{NB}^{\mathrm{a}}, 64$ & - & 3 & $10.9 \pm 0.2$ \\
\hline 2 & 33 & $\mathrm{NB}, 62$ & - & 5 & $11.4 \pm 0.4$ \\
\hline 3 & 33 & $\mathrm{NB}, 60$ & - & 7 & $12.6 \pm 0.2$ \\
\hline 4 & 33 & $\mathrm{NB}, 61$ & - & 6 & $13.1 \pm 0.3$ \\
\hline 5 & 33 & $\mathrm{NB}, 60$ & 1 & 6 & $17.7 \pm 0.2$ \\
\hline 6 & 33 & $\mathrm{NB}, 59$ & 2 & 6 & $19.6 \pm 0.3$ \\
\hline 7 & 33 & $\mathrm{AP}^{\mathrm{b}}, 59$ & 2 & 6 & $15.3 \pm 0.2$ \\
\hline 8 & 33 & $\mathrm{DBP}^{\mathrm{c}}, 59$ & 2 & 6 & $14.7 \pm 0.4$ \\
\hline 9 & 33 & $\mathrm{NB}, 63$ & 2 & 6 & $3.7 \pm 0.4$ \\
\hline
\end{tabular}

${ }^{\mathrm{a}} \mathrm{NB}=$ Nitrobenzene; ${ }^{\mathrm{b}} \mathrm{AP}=$ Acetophenon; ${ }^{\mathrm{c}} \mathrm{DBP}=$ Dibutyl phthalate. 


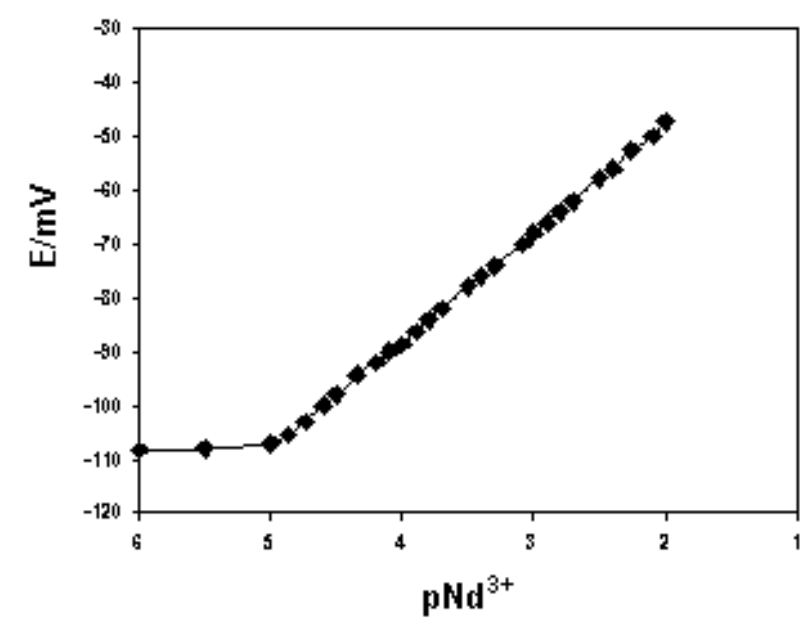

Figure 3. Calibration curve of the $\mathrm{Nd}^{3+}$ membrane sensor based on FPD (membrane No. 6) in $\mathrm{pH}=4.5$.

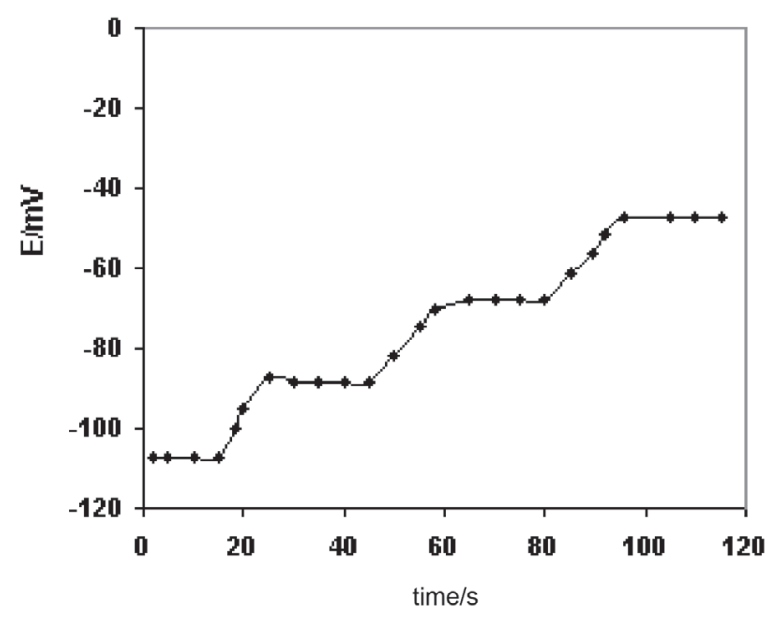

Figure 4. Dynamic response time of the $\mathrm{Nd}^{3+}$ membrane sensor (membrane No. 6) over a $1.0 \times 10^{-5}$ to $1.0 \times 10^{-2} \mathrm{~mol} \mathrm{~L}^{-1}$ solution of neodymium ions.

revealed that the absence of a proper additive causes the sensitivity of the FPD based membrane to be relatively low (No. 4 with a slope of $13.1 \mathrm{mV}$ per decade) while, the addition of about $2 \%$ of $\mathrm{KTpClPB}$, as a suitable additive, in the membrane will improve the sensitivity of the neodymium membrane electrode considerably (no. 6 with slope $19.6 \mathrm{mV}$ per decade).

\section{Calibration curve}

The optimum equilibration time for the neodymium membrane sensor in the presence of $1.0 \times 10^{-2} \mathrm{~mol} \mathrm{~L}^{-1}$ neodymium nitrate was $24 \mathrm{~h}$, after which it would generates stable potentials in contact with the neodymium solutions. The proposed sensor displays a linear response to the activity of the neodymium ion in the range $1.0 \times$ $10^{-5}$ to $1.0 \times 10^{-2} \mathrm{~mol} \mathrm{~L}^{-1}$ (Figure 2). The slope of the calibration curve was $19.6 \pm 0.3 \mathrm{mV}$ per decade. The limit of detection, as determined from the intersection of the two extrapolated segments of the calibration curve, was $7.0 \times 10^{-6} \mathrm{~mol} \mathrm{~L}^{-1}$.

For stability and lifetime evaluation, three sensors were chosen and using $1 \mathrm{~h}$ per day, and their slopes and detection limits were monitored. This experiment revealed that after six weeks, only a very slight decrease in the slopes and detection limits were observed (from $19.6 \pm$ 0.3 and $7.0 \times 10^{-6}$ to $18.7 \pm 0.4 \mathrm{mV}$ per decade and $1.0 \times$ $10^{-5} \mathrm{~mol} \mathrm{~L}^{-1}$, respectively).

\section{Dynamic response time}

Dynamic response time is one of the most important factors for the evaluation of any ion-selective electrode. In this report, the practical response times of the sensor were recorded by changing the neodymium ion concentration in solution, over a $1.0 \times 10^{-2}$ to $1.0 \times 10^{-5} \mathrm{~mol} \mathrm{~L}^{-1}$. The actual potentials versus time traces are shown in Figure 4. As it is seen, in whole concentration range the electrode reaches its equilibrium response very fast $(<15 \mathrm{~s})$.

To evaluate the reversibility of the electrode, a similar procedure in the opposite direction was adopted. The measurements were performed in the sequence of high-tolow (from $1.0 \times 10^{-2}$ to $1.0 \times 10^{-3} \mathrm{~mol} \mathrm{~L}^{-1}$ ) sample concentrations and the results showed that, the potentiometric responses of the electrode was reversible; although the time needed to reach equilibrium value $(35 \mathrm{~s})$ was longer than that of low-to-high sample concentrations (1).

\section{The effect of the $p H$}

The effect of the $\mathrm{pH}$ of the test solution $\left(1.0 \times 10^{-3} \mathrm{~mol}\right.$ $\mathrm{L}^{-1}$ neodymium ions) on the potential response of the sensor was investigated in the $\mathrm{pH}$ range $2.0-10.0$ (the $\mathrm{pH}$ of solutions was adjusted by the $0.1 \mathrm{~mol} \mathrm{~L}^{-1} \mathrm{HNO}_{3}$ or $\mathrm{KOH}$ ) and the results are illustrated in Figure 5. As can be seen from Figure 5, the potential response of the sensor is independent on $\mathrm{pH}$ in the range 4.0-8.0, beyond which the potential changes considerably. The observed drift at higher alkali media could be due to the formation of insoluble $\mathrm{Nd}(\mathrm{OH})_{3}$ in solution. The observed increase in the potential at the acidic solutions indicates that the membrane responds to the proton (protonation of nitrogen atoms of ion carrier in the membrane).

\section{Selectivity}

Potentiometric selectivity coefficients of the proposed sensor were evaluated by the matched potential method 
(MPM) ${ }^{29}$ According to MPM, the specified activity (concentration) of the primary ion $\left(\mathrm{Nd}^{3+}\right)$ is added to a reference solution, and the potential is measured. In a separation experiment interfering ions $(B)$ are successively added to an identical reference solution until the measured potential matched that obtained before by adding the primary ions. The matched potential method selectivity coefficient, $\mathrm{K}^{\mathrm{MPM}}$, is then given by the resulting primary ion to interfering ion activity (concentration) ratio, $\mathrm{K}_{\mathrm{Nd}^{3+}, \mathrm{B}}=\mathrm{a}_{\mathrm{Nd}^{3+}} / \mathrm{a}_{\mathrm{B}}$. The experimental conditions employed and the resulted values for the neodymium membrane sensor are given in Table 2 . As can be seen, for the lanthanide ions with close properties to neodymium ions (gadolinum, lanthanum, and samarium ions), the selectivity coefficients are smaller than $2.7 \times 10^{-2}$ and for other ions tested (smaller ionic radius), selectivity coefficients are smaller than $8.9 \times 10^{-3}$.

Table 2. The selectivity coefficients of various interfering cations for $\mathrm{Nd}^{3+}$ membrane sensor

\begin{tabular}{lcc}
\hline Ion & $\log \mathrm{K}^{\mathrm{MPM}}$ & $\log \mathrm{K}^{\mathrm{SSM}}$ \\
\hline $\mathrm{Na}^{+}$ & -2.6 & -2.9 \\
$\mathrm{~K}^{+}$ & -2.6 & -2.7 \\
$\mathrm{Mg}^{2+}$ & -2.5 & -2.8 \\
$\mathrm{Ca}^{2+}$ & -2.4 & -2.6 \\
$\mathrm{Cu}^{2+}$ & -2.0 & -2.1 \\
$\mathrm{La}^{3+}$ & -1.6 & -1.7 \\
$\mathrm{Gd}^{3+}$ & -1.8 & -1.9 \\
$\mathrm{Sm}^{3+}$ & -1.5 & -1.7 \\
$\mathrm{Dy}^{3+}$ & -2.1 & -2.3 \\
$\mathrm{Yb}^{3+}$ & -2.2 & -2.3 \\
\hline
\end{tabular}

\section{Stability and lifetime}

The lifetime of the Nd(III) membrane sensor were tested over a period of 70 days. During this period, the electrodes were in daily use over an extended period of time (one hour per day), and the results are given in Table 3. As can be seen from Table 3, after 49 days a very slight gradual decrease and increase in the slopes and detection limit was observed respectively. This is due to the leaking

Table 3. The lifetime of the $\mathrm{Nd}^{3+}$ membrane sensor

\begin{tabular}{lcc}
\hline Week & Slope / $(\mathrm{mV}$ per decade $)$ & Detection Limit \\
\hline First & $19.6 \pm 0.3$ & $7.0 \times 10^{-6} \mathrm{~mol} \mathrm{~L}^{-1}$ \\
Second & $19.5 \pm 0.6$ & $8.0 \times 10^{-6} \mathrm{~mol} \mathrm{~L}^{-1}$ \\
Third & $19.3 \pm 0.2$ & $8.5 \times 10^{-6} \mathrm{~mol} \mathrm{~L}^{-1}$ \\
Fourth & $19.0 \pm 0.3$ & $9.3 \times 10^{-6} \mathrm{~mol} \mathrm{~L}^{-1}$ \\
Fifth & $18.8 \pm 0.5$ & $9.5 \times 10^{-6} \mathrm{~mol} \mathrm{~L}^{-1}$ \\
Sixth & $18.6 \pm 0.3$ & $9.9 \times 10^{-6} \mathrm{~mol} \mathrm{~L}^{-1}$ \\
Seventh & $18.1 \pm 0.4$ & $1.0 \times 10^{-5} \mathrm{~mol} \mathrm{~L}^{-1}$ \\
Eighth & $17.5 \pm 0.2$ & $4.0 \times 10^{-5} \mathrm{~mol} \mathrm{~L}^{-1}$ \\
Ninth & $17.0 \pm 0.5$ & $7.2 \times 10^{-5} \mathrm{~mol} \mathrm{~L}^{-1}$ \\
Tenth & $16.2 \pm 0.7$ & $8.7 \times 10^{-5} \mathrm{~mol} \mathrm{~L}^{-1}$ \\
\hline
\end{tabular}

of membrane ingredients from membrane to the solution. This kind of behavior has been already seen for the most of introduced liquid membrane sensors.

Table 4. Determination of Nd(III) ions in various binary mixtures

\begin{tabular}{|c|c|c|}
\hline $\mathrm{Nd}^{3+} /\left(\mathrm{mol} \mathrm{L}^{-1}\right)$ & Added cation / $\left(\mathrm{mol} \mathrm{L}^{-1}\right)$ & Recovery / (\%) \\
\hline $5.0 \times 10^{-5}$ & $\mathrm{Na}^{+}\left(5.0 \times 10^{-3}\right)$ & $102.2 \pm 0.2$ \\
\hline $5.0 \times 10^{-5}$ & $\mathrm{~K}^{+}\left(5.0 \times 10^{-3}\right)$ & $102.3 \pm 0.3$ \\
\hline $5.0 \times 10^{-5}$ & $\mathrm{Ca}^{2+}\left(5.0 \times 10^{-3}\right)$ & $103.5 \pm 0.2$ \\
\hline $5.0 \times 10^{-5}$ & $\operatorname{Mg}^{2+}\left(5.0 \times 10^{-3}\right)$ & $102.6 \pm 0.4$ \\
\hline $5.0 \times 10^{-5}$ & $\mathrm{Cu}^{2+}\left(2.5 \times 10^{-3}\right)$ & $99.7 \pm 0.2$ \\
\hline $5.0 \times 10^{-5}$ & $\mathrm{La}^{3+}\left(1.2 \times 10^{-3}\right)$ & $104.4 \pm 0.4$ \\
\hline $5.0 \times 10^{-5}$ & $\mathrm{Sm}^{3+}\left(2.5 \times 10^{-3}\right)$ & $103.6 \pm 0.3$ \\
\hline $5.0 \times 10^{-5}$ & $\mathrm{Gd}^{3+}\left(2.5 \times 10^{-3}\right)$ & $103.5 \pm 0.2$ \\
\hline $5.0 \times 10^{-5}$ & $\operatorname{Dy}^{3+}\left(2.5 \times 10^{-3}\right)$ & $103.3 \pm 0.4$ \\
\hline $5.0 \times 10^{-5}$ & $\mathrm{Yb}^{3+}\left(2.5 \times 10^{-3}\right)$ & $102.2 \pm 0.4$ \\
\hline
\end{tabular}

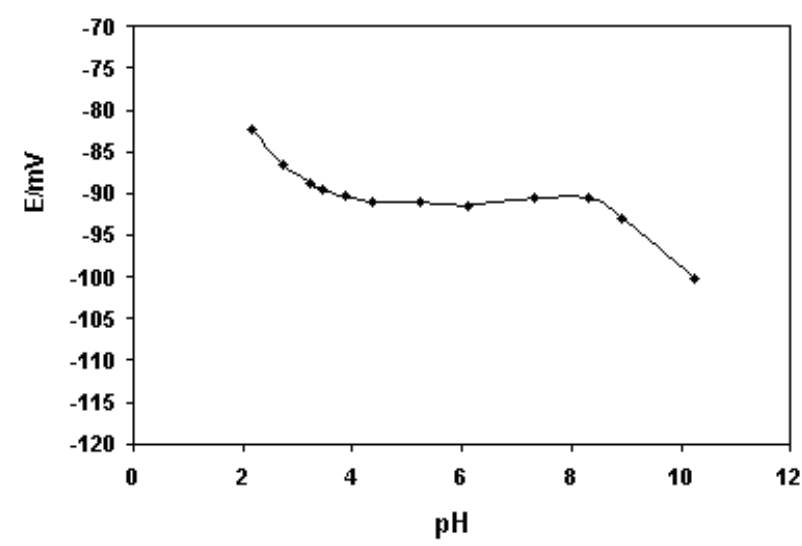

Figure 5. Effect of the $\mathrm{pH}$ of the test solution of $1.0 \times 10^{-3} \mathrm{~mol} \mathrm{~L}^{-1}$ neodymium ions on the potential response of the $\mathrm{Nd}^{3+}$ ion-selective electrode based on FPD (membrane no. 6).

\section{Analytical applications}

The proposed sensor was used as an indicator electrode in the titration of $25.0 \mathrm{~mL}$ neodymium solution $(1.0 \times$ $\left.10^{-3} \mathrm{~mol} \mathrm{~L}^{-1}\right)$ with a standard EDTA solution $\left(1.0 \times 10^{-1}\right.$ mol L-1) with the $\mathrm{pH}$ of 10.0 , and the resulted titration curve is given in Figure 6, that has a very sharp end point. As can be seen, the amount of $\mathrm{Nd}^{3+}$ ions in solution can be determined with the electrode accurately $(1.0 \pm 0.1 \times$ $10^{-3} \mathrm{~mol} \mathrm{~L}^{-1}$ ).

The sensor was applied to direct monitoring of $\mathrm{Nd}^{3+}$ in various binary mixtures, and the results are summarized in Table 4. As it is obvious, the recovery of $\mathrm{Nd}^{3+}$ ions is very good (97.7-104.4\%). This is due to the relatively good selectivity of the proposed sensor.

\section{Comparison}

Table 5 compares the selectivity coefficients, Detection limit, and dynamic linearity range of the proposed $\mathrm{Nd}(\mathrm{III})$ 
Table 5. Comparison of the characteristics of the proposed sensor and the best reported $\mathrm{Nd}(\mathrm{III})$ sensors

\begin{tabular}{|c|c|c|c|c|c|}
\hline Sensor & Linear Dynamic Range & Limit of Detection & $\begin{array}{l}\text { Slope / } \\
(\mathrm{mV})\end{array}$ & $\begin{array}{l}\log \mathrm{K}^{\mathrm{SSM} /} \\
\text { (transition metal) }\end{array}$ & $\begin{array}{l}\log \mathrm{K}^{\mathrm{SSM}} / \\
\text { (alkali and alkali metal ion) }\end{array}$ \\
\hline Ref. 25 & $1.0 \times 10^{-6}$ to $1.0 \times 10^{-2} \mathrm{~mol} \mathrm{~L}^{-1}$ & $7.9 \times 10^{-7} \mathrm{~mol} \mathrm{~L}^{-1}$ & $20.1 \pm 0.2$ & $\begin{array}{l}\mathrm{La}^{3+}(-1.4) ; \mathrm{Gd}^{3+}(-1.4) \\
\mathrm{Sm}^{3+}(-1.6) ; \mathrm{Yb}^{3+}(-1.2) \\
\mathrm{Cu}^{2+}(-1.5)\end{array}$ & $\begin{array}{l}\mathrm{Na}^{+}(-2.9) ; \mathrm{K}^{+}(-2.8) \\
\mathrm{Mg}^{2+}(-2.8) ; \mathrm{Ca}^{2+}(-2.5)\end{array}$ \\
\hline This work & $1.0 \times 10^{-5}$ to $1.0 \times 10^{-2} \mathrm{~mol} \mathrm{~L}^{-1}$ & $7.0 \times 10^{-6} \mathrm{~mol} \mathrm{~L}^{-1}$ & $19.6 \pm 0.3$ & $\begin{array}{l}\mathrm{La}^{3+}(-1.7) ; \mathrm{Gd}^{3+}(-1.9) \\
\mathrm{Sm}^{3+}(-1.7) ; \mathrm{Yb}^{3+}(-2.3) \\
\mathrm{Dy}^{3+}(-2.3) ; \mathrm{Cu}^{2+}(-2.1)\end{array}$ & $\begin{array}{l}\mathrm{Na}^{+}(-2.9) ; \mathrm{K}^{+}(-2.7) ; \\
\mathrm{Mg}^{2+}(-2.8) ; \mathrm{Ca}^{2+}(-2.6)\end{array}$ \\
\hline
\end{tabular}

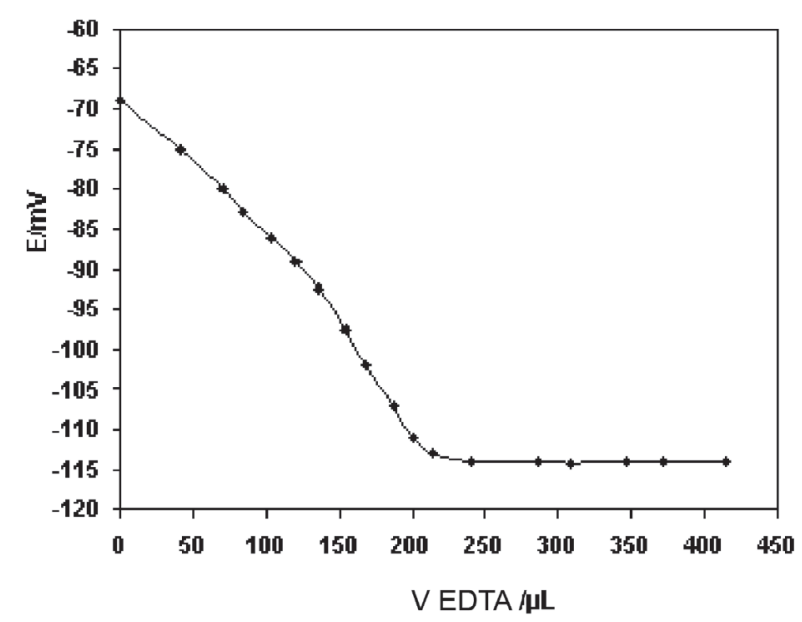

Figure 6. Potentiometric titration curve of $25.0 \mathrm{~mL} \mathrm{Nd}^{3+}\left(1.0 \times 10^{-3} \mathrm{~mol}\right.$ $\mathrm{L}^{-1}$ ) with $10^{-1}$ mol L-1 EDTA using the membrane no. 6 as an indicator electrode in $\mathrm{pH}=10.0$.

sensor, with previously $\mathrm{Nd}(\mathrm{III})$ electrode reported in the literature ${ }^{25}$. As can be seen from Table 5, the proposed $\mathrm{Nd}(\mathrm{III})$ sensor in the terms of selectivity coefficient, specially for transition metals, is better than the previously reported sensor.

\section{Acknowledgment}

The authors express their appreciation to the University of Tehran Research Council for financial support of this work.

\section{References}

1. Rao, G. S. S.; Upadhyay, V. K.; Jain, R. C.; J. Appl. Polym. Sci. 1999, 71, 595.

2. Bodrova, V. S.; Piskareva, E. P.; Shelokhneva, L. F.; Poletaeva, I. A.; Vysokomol. Soedin. 1998, 40, 1741.

3. Marczenko, Z.; Separation and Spectrophotometric Determination of Elements, $2^{\text {nd }}$ ed., Ellis Horwood Ltd.: Chichester, 1986.

4. Bakker, E.; Bühlmann, P.; Pretsch, E.; Chem. Rev. 1997, 97, 3083.
5. Ganjali, M. R.; Daftari, A.; Qomi, M.; Norouzi, P.; Sens. Actuators, B 2004, 98, 192.

6. Ganjali, M. R.; Daftari, A.; Rezapour, M.; Talanta 2003, 59, 613.

7. Shamsipur, M.; Yousefi, M.; Hosseini, M.; Ganjali, M. R.; Anal. Chem. 2002, 74, 5538.

8. Hassanien, M. M.; Abou-El-Sherbini, K. S.; Mostafa, G. A. E.; Talanta 2003, 59, 392.

9. Itot, T.; Goto, C.; Noguchi, K.; Anal. Chim. Acta 2001, 443, 41.

10. Susheel, K.; Mittal, S. K.; Kumar, A.; Sharma, H. K.; Talanta 2004, 62, 801.

11. Ganjali, M. R.; Kiani, R.; Shamsipur, M.; Poursaberi, T.; Salavati-Niasari, M.; Talebpour, Z.; Emami, M.; Electroanalysis 2004, 16, 1002.

12. Gupta, V.; Suresh, C.; Chandra, C.; Anal. Chim. Acta 2003, 486, 199.

13. Ganjali, M. R.; Mirnaghi, F. S.; Norouzi, P.; Adib, M. Sens. Actuators, B 2006, 115, 374.

14. Karami, H.; Mousavi, M. H.; Shamsipour, M.; Yavari, I.; Alizadeh, A. A.; Anal. Lett. 2003, 36, 1065.

15. Ganjali, M. R.; Norouzi, P.; Adib, M.; Ahmadalinezhad, A.; Anal. Lett. 2006, 39, 1075.

16. Ganjali, M. R.; Pourjavid, M. R.; Rezapour, M.; Haghgoo, S.; Sens. Actuators, B 2003, 89, 21.

17. Ganjali, M. R.; Norouzi, P.; Shamsolahrari, L.; Ahmadi, A. Sens. Actuators, B 2006, 114, 713.

18. Ganjali, M. R.; Rezapour, M.; Pourjavid, M. R.; Haghgoo, S.; Anal. Sci. 2004, 20, 1007.

19. Ganjali, M. R.; Norouzi, P.; Tamaddon, A.; Adib, M.; Sens. Actuators, B 2006, 114, 855.

20. Ganjali, M. R.; Rahimi, M.; Maddah, B.; Moghimi, A.; Borhany, S.; Anal. Sci. 2004, 20, 1427.

21. Ganjali, M. R.; Tahami, M.; Shamsipur, M.; Poursaberi, T.; Haghgoo, S.; Hosseini, M.; Electroanalysis 2003, 15, 1038.

22. Ganjali, M. R.; Naji, L.; Poursaberi, T.; Shamsipur, M.; Haghgoo, S.; Anal. Chim. Acta 2003, 475, 59.

23. Ganjali, M. R.; Matloobi, P.; Ghorbani, M.; Norouzi, P.; Salavati-Niasari, M.; Bull. Korean Chem. Soc. 2005, 26, 38.

24. Ganjali, M. R.; Ravanshad, J.; Hosseini, M.; Salavati-Niasari, M.; Pourjavid, M. R.; Baezzat, M. R.; Electroanalysis 2004, 16,1771 . 
25. Shamsipur, M.; Hosseini, M.; Alizadeh, K.; Mousavi, M. F.; Garau, A.; Lippolis, V., Yari, A.; Anal. Chem. 2005, 77, 276.

26. Ammann, E.; Pretsch, P.; Simon, W.; Lindner, E.; Bezegh, A.; Pungor, E.; Anal. Chim. Acta 1985, 171, 119.

27. Eugster, R.; Gehrig, P. M.; Morf, W. E.; Spichiger, U.; Simon, W.; Anal. Chem. 1991, 63, 2285.
28. Rosatzin, T.; Bakker, E.; Suzuki, K.; Simon, W.; Anal. Chim. Acta 1993, 280, 197.

29. Umezawa, Y.; Umezawa, K.; Sato, H.; Pure Appl. Chem. 1995, $67,507$.

Received: February 22, 2006 Published on the web: August 30, 2006 